\author{
서울시 환경보건정책 로드맵 수립 \\ 임지애 · 권호장 · 김신범* · 최영은* · 구슬기* · 정회성** · 김명한** · 최경호***† \\ 단국대학교 예방의학교실, *노동환경건강연구소, **(사)환경과문명, ***서울대학교 보건대학원

\section{Process and Results of Seoul Metropolitan Government's Environmental Health Policy Road Map} \\ Ji-Ae Lim, Ho-Jang Kwon, Shinbum Kim*, Youngeun Chou*, Seulgi Gu*, \\ Hoi-Seong Jeong**, Myung Han Kim**, and Kyungho Choi***† \\ Department of Preventive Medicine, Dankook University College of Medicine, Korea \\ *Wonjin Institute for Occupational and Environmental Health, Seoul, Korea \\ **Institute for the Environment and Civilization, Seoul, Korea \\ ***School of Public Health, Seoul National University, Seoul, Korea
}

\begin{abstract}
Objectives: The purpose of this study is to introduce the establishment process and results of the Seoul Metropolitan Government's road map on environmental health policy.

Methods: The process consisted of expert group meetings, civic participation, research, and questionnaire survey for priority environmental health policy agenda items in Seoul.

Results: The announced vision for the environmental health policy was "a healthy environment, safety in Seoul". This policy was established in order to define environment health policy initiatives for a period of five years with an aim to protect Seoul citizens' health from hazardous environmental factors. The resulting Seoul environmental health policy consisted of four areas and 16 key agenda items. The four areas were "Protection for children against hazardous materials", "Enhancement of health and safety of all", "Carcinogen-free and endocrine-disrupting chemical-free Seoul (reducing environmental exposure to hazardous materials), and "Establish the foundation of environmental health policy". Sixteen key agenda items include the enhancement of management of spaces for children, certification of environmental health status at schools, establishment of a unit responsible for the environmental health of children, strengthening environmental health management for susceptible populations (children, the aged, and the socioeconomically vulnerable), management of hazardous materials, physical hazardous factors (noise, radiation, etc.), indoor air quality, and the enhancement of monitoring, research, and regulation of environment health.

Conclusion: The Seoul Metropolitan Government established an environmental health policy road map for a five-year period (2013-2017). To implement this environmental health policy, budget allocation, and detailed execution plans are required.
\end{abstract}

Keywords: Environmental health, Municipal government, Policy, Road map, Seoul

\footnotetext{
${ }^{\dagger}$ Corresponding author: School of Public Health, Seoul National University, Seoul, Korea, 1, Gwank-ro, Gwanak-gu, Seoul, Korea, 151-742, Tel: +82-2-880-2738, E-mail: kyungho@snu.ac.kr

Received: 15 October 2014, Revised: 21 October 2014, Accepted: 28 October 2014
} 


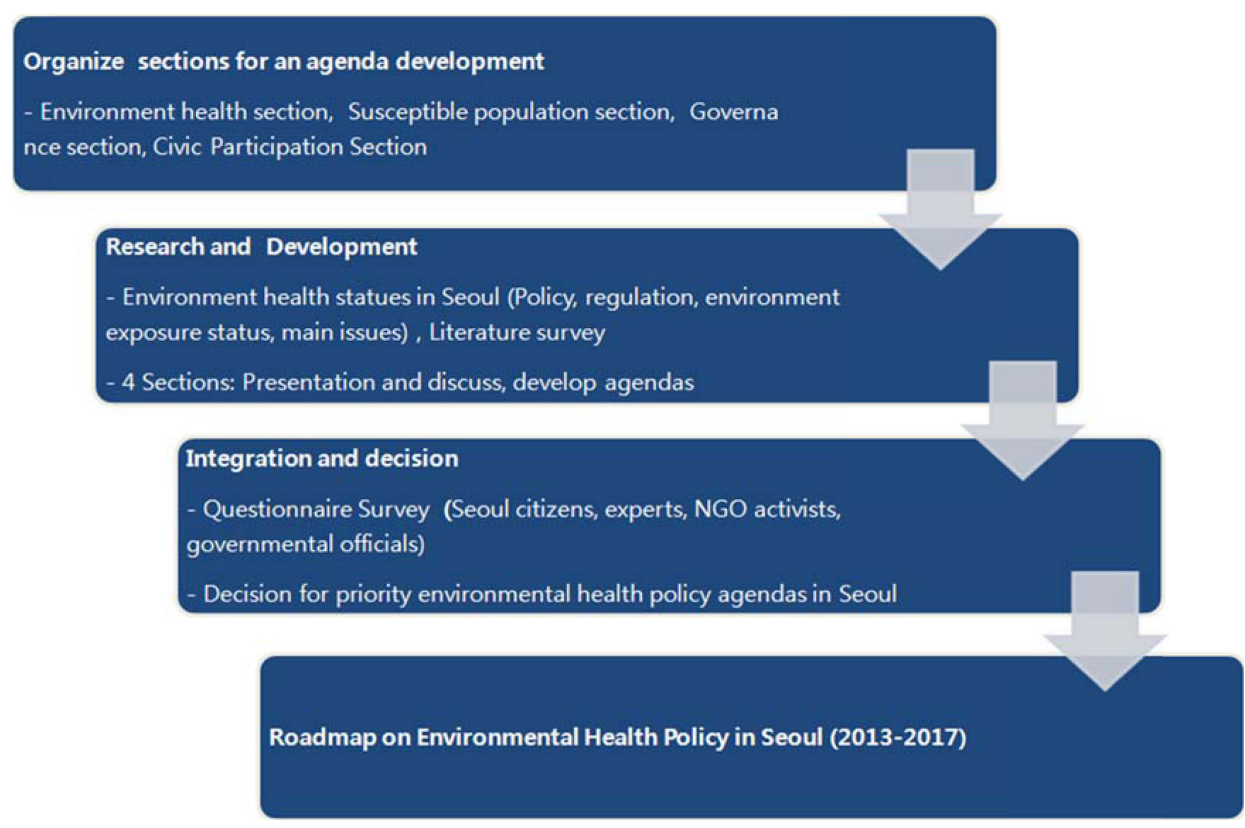

Fig. 1. Process of developing the Seoul metropolitan government's road map on environmental health policy.

\section{I. 서 론}

최근에 들어 대기, 수질, 토양, 폐기물 등 각 환경 매체별 관리에서 벗어나 수용체(인간) 중심의 통합 관리의 필요성이 인식되고 사전예방의 원칙이 강조 되고 있다. 이러한 맥락에서 우리나라 환경부는 2006 년부터 국민 건강 보호를 위한 환경보건종합계획을 수립하여 시행하고 있다. ${ }^{1)}$ 또한 『환경보건법』 제5 조에서는 국가뿐 아니라 지방자치단체도 환경유해인 자가 수용체에 미치는 영향을 항상 파악하고 환경유 해인자로부터 수용체를 보호하기 위한 필요한 시책 을 세우고 시행하여야 한다고 정하고 있다. ${ }^{2)}$

서울시는 $605 \mathrm{~km}^{2}$ 의 면적에 인구 1,012 만 명(2014 년 기준)으로 한국인의 약 $20 \%$ 가 거주하는 대한민 국 최대의 도시이다. 서울의 인구밀도(2005년 기준) 는 17,025 명 $/ \mathrm{km}^{2}$ 으로 국내 최대일 뿐 아니라 뉴욕 10,483 명 $/ \mathrm{km}^{2}$, 동경 13,650 명 $/ \mathrm{km}^{2}$ 보다 매우 높은 수준이다. ${ }^{3)}$ 도시환경은 환경친화성(environmental soundness)과 안전(safety), 활력(vitality), 편리성 (convenience), 쾌적성(amenity)을 기본 요소로 하지 만4) 서울시의 경우 높은 인구밀도로 인해 안전과 환 경의 문제가 중요한 정책 과제가 되고 있다.
서울시의 환경 현황을 외국의 주요 도시와 비교해 보면 대기오염(미세먼지, 이산화 질소, 오존 등)의 경 우 베이징 등 개발도상국에 비해서는 양호하다. 하 지만 선진국과 비교할 경우 오염 수준이 높은 편이 며5) 화학물질 노출과 연관이 높은 아토피 피부염, 알 레르기 비염, 천식 등 환경성질환도 계속 증가하는 추세이다. ${ }^{6}$ 또한 기후변화로 인해 폭염, 열대야, 집중 호우, 곤충과 기생충 등의 매개 질환, 대기오염, 알 레르기 환자 등이 증가하고 있다. ${ }^{7,8)}$ 서울시민들의 건 강에 대한 인식 수준과 노력은 증가하고 있으나 생 활환경에 대한 만족도는 낮은 편이다. ${ }^{9}$

서울시는 환경이 시민 건강에 미치는 영향의 중요 성을 인식하고, 2012년도부터 환경 보건 전담 부서 를 설치하고 서울시 환경보건조례 제정 ${ }^{10}$ 과 아토피 없는 건강한 서울 만들기 ${ }^{11)}$ 등 주요 환경보건사업을 추진해왔다. 향후 환경보건사업을 체계적이고 지속 적으로 추진하기 위해 서울시에 특화된 중장기 환경 보건정책을 수립할 필요성이 증대됨에 따라 서울시 환경보건정책 로드맵을 구축하게 되었다. 서울시 환 경보건정책 로드맵은 환경보건 분야 전문가, 시민사 회단체, 관련 공무원들이 참여하고 환경보건정책에 대한 시민의견을 반영한 결과를 종합하여 2013년부 
터 향후 5 년간 서울시에서 추진할 환경보건정책의 비전과 목표, 중점 추진분야 및 세부과제, 연차별 추 진 계획을 포함한 것이다. 본 논문에서는 지방정부 의 환경보건정책 수립의 사례로 서울시 환경보건정 책 수립과정을 소개하고, 선정된 주요 정책 및 세부 과제와 서울시 환경보건정책 이행 방안을 제시하였다.

\section{II. 연구방법}

서울시 환경보건정책 수립을 위해 전문가 분과와 시민참여 분과의 운영, 시민 설문조사의 수행, 국내 외 관련 정책 및 자료의 분석을 진행하였다(Fig. 1). 즉 전문가 분과와 시민참여분과에서 정책과제를 제 안하였고, 이들을 토대로 추가적 자료분석을 통해 서 울시 환경보건정책 방향과 과제를 선정하였다. 시민 설문조사를 통해 서울시민의견을 반영하고 실현가능 성, 사업연계성을 고려하여 최종 서울시 환경보건정 책 과제를 선정하게 되었다. 주요 연구 내용은 아래 와 같다.

\section{1. 서울시 환경보건현황 및 국내외 관련 정책 및 법률 검토}

서울시의 환경 및 보건 관련 자료분석을 통해 서 울시 환경보건현황과 우선 과제를 파악하였다. 또한 서울시가 현재 추진하고 있는 환경보건사업의 성과 와 정책방향성을 파악하였다. 중앙정부와 지방정부 의 환경보건법규와 계획, 실행 상황을 파악하고 효 과적인 역할 분담과 협력, 상호 보완할 수 있는 세 부 실천 과제를 발굴하였다. 해외사례 조사분석을 통 해 서울시 특성에 맞는 환경보건정책 이행전략을 개 발하였다.

\section{2. 분과 구성 및 운영}

본 연구에는 환경보건, 예방의학, 거버넌스 분야 전문가들과, 환경 및 환경보건, 지역사회 $\mathrm{NGO}$ 및 소 비자 생활협동조합 등 환경보건 관련 시민사회단체 전문가가 연구진으로 참여하였으며, 환경보건 관련 국가 및 지방정부 공무원의 의견을 반영하였다. 연 구 수행을 위해 세부 분과인 환경보건분과, 민감계 층분과, 거버넌스분과, 시민참여분과를 구성하고 각 분과 별 자문위원을 구성하여, 수차례에 걸친 발제 와 토론을 거쳐 서울시의 환경보건실태를 검토하고
주요 환경보건정책 과제에 대해 논의하고 주요 정책 과제를 도출하였다. 시민소통분과에서는 제안된 환 경보건정책 과제들은 취합, 정리하여 시민의견 수렴 을 위한 온라인 설문 조사를 기획, 진행하였다.

\section{3. 시민의견 수렴을 위한 온라인 설문조사}

온라인 서울시민 설문조사는 환경보건분과, 민감 계층분과, 거버넌스분과, 시민소통분과에서 발굴한 환경보건정책과제에 대한 시민의견을 취합하기 위한 목적으로 진행하였다. 서울의 주요 환경보건문제(대 기오염, 다중이용시설의 실내공기, 생활속 유해화학 물질, 생활 방사선과 전자파)에 대한 의견과 바람직 한 환경보건 정책 방향(기후변화 대응, 건강증진을 위한 실외활동 기반 구축, 어린이 - 청소년 환경보건, 노령인구의 환경보건, 경제적 취약계층의 환경보건 분야)에 대한 의견을 물었다.

\section{III. 연구결과}

\section{1. 서울시 환경보건현황 및 국내외 관련 정책 및}

\section{법률 검토}

우리나라 중앙정부의 환경보건종합계획(2011 2020) 과 환경보건법은 중앙정부뿐 아니라 지방자치 정부 차원의 환경보건정책 수립을 제안하고 있다. 유럽 의 경우도 1990년대 이후 국가차원의 환경보건활 동계획(National Environmental Health Action Plan, NEHAP)이 추진되면서 지방정부의 환경보건 활동계획(Local Environmental Health Action Plan, LEHAP) 수립 필요성이 자연스럽게 제기된 바 있다. 현재 서울시는 환경보건관리 체계 구축, 생활속 발 암물질 예방관리, 어린이 활동공간 환경안전관리, 환 경성질환 예방교육 등 중점 추진계획을 수립하고 추 진하고 있다. 서울시 보건환경연구원, 통계연보 등 자료를 바탕으로 서울시 환경보건현황을 파악하고 우선순위가 높은 환경보건 분야의 과제를 발굴하였 다. 서울시가 우선적으로 추진해야 할 환경보건과제 로 대기환경 개선 $\left(\mathrm{NO}_{2}, \mathrm{PM}_{10}\right)$ 과 다중이용시설의 실 내공기질 개선, 생활속 환경유해물질 관리, 기후변화 대응대책 마련 등이 파악되었다.

\section{2. 분과 구성 및 운영}

서울시의 환경보건 현황을 이해하고 필요한 환경 
보건 의제를 발굴하기 위한 목적으로 환경보건분과, 민감계층분과, 거버넌스분과, 시민참여분과를 구성하 고, 각 분과별 관련 전문가를 자문위원으로 위촉하 였다. 분과별로 발제 및 토론을 통해 서울시 환경보 건정책 의제를 개발하였다.

환경보건분과는 서울시민의 유해물질 노출 수준 파 악, 환경보건분야 국제동향과 협력 모색, 중앙정부와 지자체의 협력 방안 마련, 건강하고 안전하고 쾌적 한 환경을 제공하기 위한 도시환경 재생기술 등 환 경보건 현황과 제도적 방안을 모색하였다. 민감계층 분과는 어린이와 청소년, 노인, 사회경제적 취약계층 등 민감계층 대상별 특성과 노출 현황을 파악하고, 민감 취약 계층별 주요 노출 요인과 우선관리가 필 요한 정책과제를 정리하였다. 거버넌스분과는 국내 외 국가 및 지자체 환경보건정책 추진현황을 파악하 고 서울시 환경보건정책 이행방안을 정리하였다. 시 민참여분과는 환경 및 환경보건, 지역사회 $\mathrm{NGO}$ 및 소비자 생활협동조합 등 참여 기관 회원들을 대상으 로 환경보건관련 정책제안을 수렴하고, 환경보건위 해소통, 지역아동센터를 기반으로 한 취약계층 아동 환경보건문제 개선, 지역사회기반연구, 환경보건교육, 생활속 유해물질 없애기 등의 의제를 개발하였다.

\section{3. 시민의견 설문 조사 결과}

설문조사는 2013년 7월 2일부터 8월 6일까지 36 일간 온라인 방식으로조사를 수행하였다. 설문조사 응답자는 총 909명으로 서울시청 홈페이지를 통해 조사에 참여한 서울시민은 674명이며 시민단체(발암 물질 없는 사회 만들기 국민행동, 아이쿱생협, 아이 건강국민연대, 여성환경연대, 전국금속노동조합, 참 교육학부모회, 한살림, 환경운동연합, 환경정의, 환경 보건시민센터) 홈페이지 링크와 배너를 통해 참여한 시민단체 활동가 및 회원은 121 명, 환경보건 관련학 회(환경보건학회, 환경독성보건학회) 배너를 통해 참 여한 환경보건분야 전문가는 118 명이었다. 조사응답 자 중 남자는 413 명 $(51 \%)$ 으로 남녀의 비율은 비슷 했으며 응답자 연령대는 19세 미만이 4명 $(0.5 \%), 20$ 39 세가 316명(39\%), 40-59세가 486명(60\%), 60세 이상이 8 명 $(1 \%)$ 로 40 대 응답자가 가장 많았다.

서울시에서 가장 중요한 환경보건문제를 두 개만 선택하라는 질문에 대해 '대기오염(45\%)'이 가장 많 은 선택을 받았으며 두 번째로는 '생활속 유해화학
물질(39\%)'이었다(Table 1). 대기오염 문제를 최우선 과제로 선택한 응답자들은, 대기오염 문제에 대처하 기 위해 서울시가 우선적으로 해결해야 할 과제로 '도 시환경 초미세먼지 관리(43\%)', ‘디젤 자동차 연소 분지 건강영향 대책 $(27 \%)$ ', '대기오염의 만성 건강 영향조사 $(20 \%)^{\prime}$ 의 순서로 선택하였다.

생활 속 유해화학물질을 중요한 환경보건문제로 선택한 응답자들은, 생활 속 유해화학물질 문제를 위 해 서울시가 우선적으로 추진해야 할 과제로 '우선 관리대상 유해물질 선정 및 저감대책 마련(34\%), '내분비계 장애물질(환경호르몬) 관리 (23\%)', '생활 용품 속 유해물질 저감을 위한 생산유통 관계자 협 약 체결 $(20 \%)^{\prime}$ 을 꼽았다(Table 1).

서울시에서 우선적으로 고려해야 할 환경보건정책 방향은 '기후변화 대응(32\%)'이였고 다음으로는 '건 강증진을 위한 실외활동 기반구축(27\%)', '어린이, 청소년 환경보건 문제(23\%)' 순 이었다(Table1). 기 후변화 대응을 위한 세부 정책으로는 '온실가스 감 축 정책 수립과 실행(37\%)'을 선택하였으며, '건강 증진을 위한 실외활동 기반 구축'을 위한 우선 과제 로는 '도심 내 자연 녹지, 공원 확충( $44 \%)$ 을 우선 과제로 꼽혔다. '어린이 청소년 환경보건'정책 수립 을 위한 우선 과제로는 '어린이, 청소년 시설 내 유 해물질 관리(32\%)'를 선택하였다(Table 1).

\section{4. 서울시 환경보건정책 수립 방향13)}

분과별 활동 및 시민 의견수렴을 통해 파악된 서 울시 환경보건정책 의제 중 서울시에서 이미 추진하 고 있던 환경보건정책(민감 계층 환경보건대책, 유 해물질 저감 및 관리, 환경성질환 조사 및 예방, 소 통 및 협력 강화)을 고려하여 서울시 환경보건정책 방향과 중점 과제를 선정하였다.

서울시 환경보건정책 비전으로 “건강한 환경, 안 심 서울”이 선정되었다. 이는 어린이, 청소년, 노령, 사회경제적 취약 계층 등 환경 보건에 취약한 집단 을 포함한 모든 서울 시민이 발암물질, 환경호르몬 과 같은 환경 유해인자로부터 안전하고 건강해야 함 을 의미한다. "건강한 환경 환경, 안심 서울"은 시민 설문조사에서 건강하고 쾌적한 도시를 지향하는 서 울을 잘 나타내는 문구로 가장 많은 선택 $(25 \%)$ 을 받 기도 하였다.

서울시 환경보건정책의 방향은 크게 4 개 분야로, 
Table 1. Results of the questionnaire survey on environmental health policy in Seoul

\begin{tabular}{|c|c|c|}
\hline Questions & Item & $\mathrm{N}(\%)$ \\
\hline \multirow{5}{*}{$\begin{array}{l}\text { The most serious } \\
\text { environment pollutant } \\
\text { problem in Seoul }\end{array}$} & Air pollution & $408(45 \%)$ \\
\hline & Indoor air pollution & $129(14 \%)$ \\
\hline & Exposure to hazardous chemical materials & $320(35 \%)$ \\
\hline & Exposure to radiation and electromagnetic waves in environment & $50(6 \%)$ \\
\hline & Total & $907(100)$ \\
\hline \multirow{5}{*}{$\begin{array}{l}\text { Priority agenda for } \\
\text { control of air pollution }\end{array}$} & Control of particulate matter & $330(43 \%)$ \\
\hline & Countermeasure for health effects of diesel combustion particulate & $207(27 \%)$ \\
\hline & Survey for chronic health effect of air pollution & $154(20 \%)$ \\
\hline & Countermeasure for yellow sand problem & $79(10 \%)$ \\
\hline & Total & $770(100 \%)$ \\
\hline \multirow{6}{*}{$\begin{array}{l}\text { Priority agenda for } \\
\text { control of } \\
\text { environmental } \\
\text { hazardous materials }\end{array}$} & Selection and control for priority hazardous materials in environment & $218(34 \%)$ \\
\hline & Reduction the use of hazardous materials(insecticide, pesticide, etc) & $85(13 \%)$ \\
\hline & Control of an exposure to endocrine disrupting chemicals in environment & $145(23 \%)$ \\
\hline & $\begin{array}{l}\text { Agreement between producer and consumer on abatement hazardous materials in } \\
\text { households products }\end{array}$ & $127(20 \%)$ \\
\hline & Release a purchase guide book for healthy and safe products & $67(10 \%)$ \\
\hline & Total & $642(100 \%)$ \\
\hline \multirow{6}{*}{$\begin{array}{l}\text { Required environment } \\
\text { health policy in Seoul }\end{array}$} & Countermeasure against climate change & $269(32 \%)$ \\
\hline & Laying the foundation for promote outdoor activity & $178(21 \%)$ \\
\hline & Environment health policy for children and adolescent & $194(23 \%)$ \\
\hline & Making an environment health policy for aging population & $47(6 \%)$ \\
\hline & Making an environment health policy for socioeconomically susceptible population & $155(18 \%)$ \\
\hline & Total & $843(100 \%)$ \\
\hline \multirow{5}{*}{$\begin{array}{l}\text { Priority agenda for } \\
\text { countermeasure against } \\
\text { climate change }\end{array}$} & Countermeasure for susceptible population in climate change & $91(17 \%)$ \\
\hline & Product basic data for climate change in Seoul & $130(24 \%)$ \\
\hline & Prepare citizen's guideline for against climate change & $116(22 \%)$ \\
\hline & Greenhouse gas reduction policy formulation and execution & $197(37 \%)$ \\
\hline & Total & $534(100 \%)$ \\
\hline \multirow{6}{*}{$\begin{array}{l}\text { Priority agenda for } \\
\text { children and adolescent } \\
\text { in environment health } \\
\text { policy }\end{array}$} & Study for infant and children environment health policy & $54(14 \%)$ \\
\hline & Establishment of the unit responsible for environmental health of children and adolescent & $44(11 \%)$ \\
\hline & Control environment pollution(air pollution, etc) in school zone & $66(17 \%)$ \\
\hline & Control of hazardous materials in facilities for children and adolescent & $126(32 \%)$ \\
\hline & Control of products containing hazardous materials for children & $98(25 \%)$ \\
\hline & Total & $388(100 \%)$ \\
\hline
\end{tabular}

(1) 어린이 건강부터 꼼꼼히 “챙기는 서울”(유해물질 로부터 어린이 보호), (2) 서울시민 모두의 건강과 안전을 지키는 “함께하는 서울”(모두의 건강과 안전 강화), (3) 서울시민 건강을 위협하는 발암물질 및 환경호르몬을 “없애는 서울"(발암물질 및 환경호르 몬 물질 제로 서울), (4) 환경보건기반 강화를 이끄

http://www.kseh.org/
는 서울"(환경보건정책 기반 구축)이다(Table 2).

\section{5. 서울시 환경보건정책 16 대 과제}

서울시 환경보건정책 4 개 분야를 중심으로 모두 16 대 과제를 선정하였다(Table 2). 4 개 분야별 16대 과제의 세부 내용은 아래와 같다.

J Environ Health Sci 2014; 40(5): 425-434 
Table 2. Results of Seoul Metropolitan Government's Environmental Health Policy Road Map

\begin{tabular}{ll}
\hline \hline \multicolumn{1}{c}{ Area } & Key Agenda \\
\hline & 1. Strengthening environment safety management for children's activity area \\
& -Strengthening environment safety management for children's activity area \\
& - Building environments for outdoor activity to healthier children \\
& -Environmental health education for care givers of children's activity area \\
I. Protection for & -Developing guidebooks for safety management for children's activity are and prevention against \\
children against & hazardous materials. \\
hazardous materials 2. Running certificate programs for school environmental health & -Running camp program for children with environmentally related diseases \\
& -Certificate program for safe schools for children (Atopy free and carcinogen free schools, Building \\
& PVC free school environment) \\
3. Establishing an administrative department for children's environmental health
\end{tabular}

1. Strengthening environmental health management for susceptible population -Strengthening management of hazardous materials to protect children -Intervention program to reduce exposure to hazardous materials through citizen participation -Healthy longevity $+10(\%)$ program for the elderly

2.Environmental health of socioeconomically susceptible class -Preparing protection measures for children in the socioeconomically susceptible class through II. Enhancement of community children center health and safety of -Strengthening environmental health management for socioeconomically susceptible class all

3. Citizen participatory environmental health projects -Carcinogen free Seoul campaign

-Organizing a citizen monitoring program for environment health

4. Education and information

-Enhancement of functions of Atopy Education and Information Center

-Production and release a pictures of prevention against environmental disease

-to provide relevant environmental health information throughout the life cycle

\begin{tabular}{|c|c|}
\hline \multirow{4}{*}{$\begin{array}{l}\text { III. Carcinogen free } \\
\text { and Endocrine } \\
\text { disrupting } \\
\text { chemicals free } \\
\text { Seoul }\end{array}$} & $\begin{array}{l}\text { 1.Management of exposure to hazardous materials } \\
\text {-Selection and management of seven priority hazardous materials } \\
\text {-Management of fine particulate matter (diesel combustion particulate) } \\
\text {-Countermeasures for exposure to artificial perfume in environment } \\
\text {-Survey on use of hazardous materials and countermeasure to reduce exposure to hazardous materials } \\
\text { in small-scale workspaces }\end{array}$ \\
\hline & $\begin{array}{l}\text { 2.Management of use of products containing hazardous materials } \\
\text {-Enactment recommendation guidelines for safety products and building information on safety } \\
\text { products } \\
\text {-Agreement between producers and consumers to reduce or remove the use of hazardous materials in } \\
\text { households products } \\
\text {-To develop and distribute purchase guidebooks for healthy and safe products }\end{array}$ \\
\hline & $\begin{array}{l}\text { 3.Management of physical risk factors in environment } \\
\text {-Noise (road traffic, aircraft noise, floor noise) } \\
\text {-Promoting measures against environment radiation and medical radiation } \\
\text {-Countermeasure against exposure to electromagnetic waves in environment }\end{array}$ \\
\hline & $\begin{array}{l}\text { 4.Improvement of indoor air quality } \\
\text {-Establish an integrated management system on indoor air quality } \\
\text {-Investigation on exposure to radon in environment } \\
\text {-Development of management indexes on integrated indoor environment. } \\
\text {-Investigation and improvement of indoor air quality among socioeconomically susceptible class. }\end{array}$ \\
\hline
\end{tabular}


Table 2. Continued

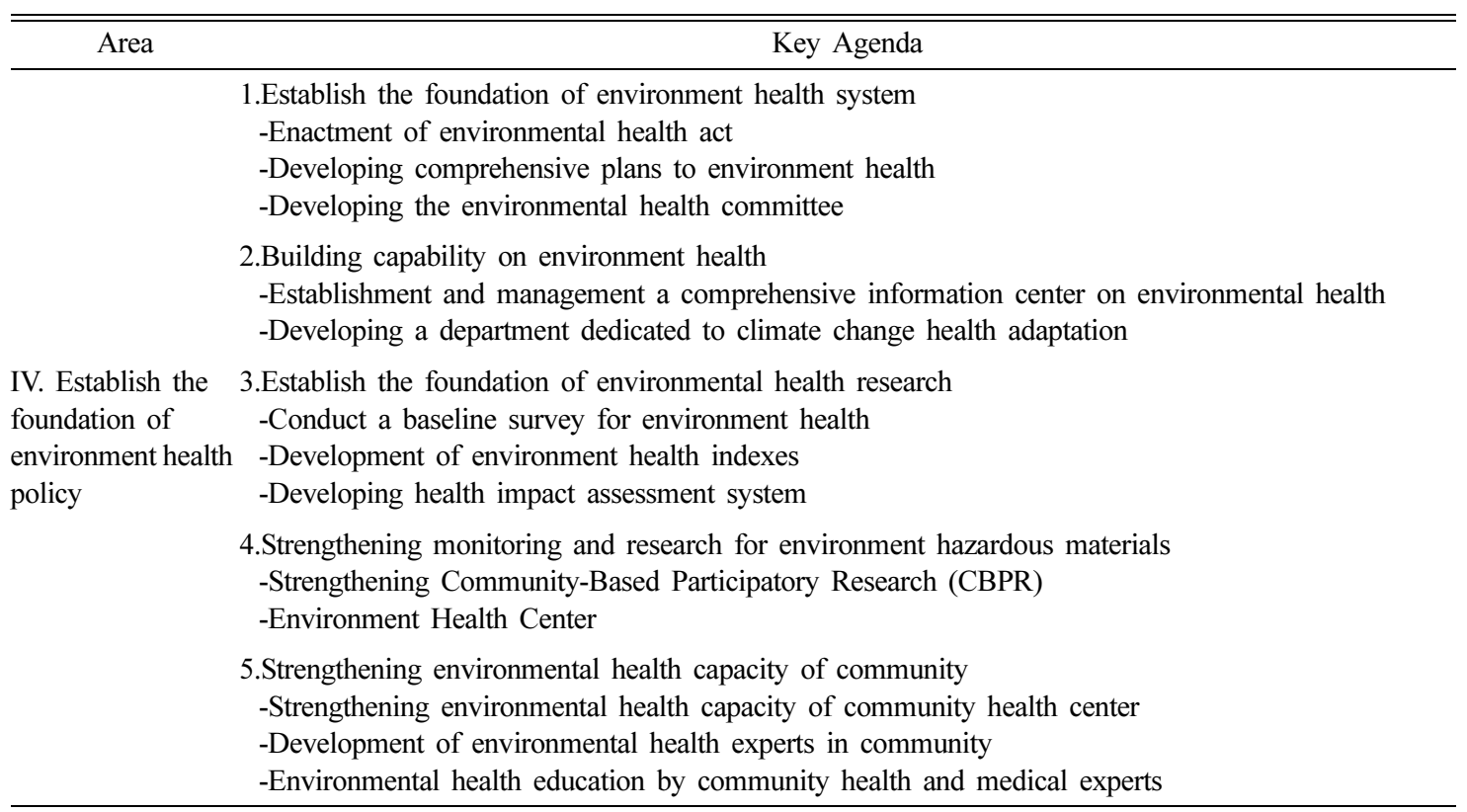

1) 유해물질로부터 어린이 보호

유해물질로부터 어린이를 보호하기 위한 우선과제 로는 어린이 활동 공간의 환경안전관리 추진과 학교 환경보건인증 및 체험 프로그램 운영, 어린이 환경보 건전담부서 설치 등이 파악되었다. '어린이 활동공간 의 안전관리 강화’를 위해 어린이 활동 공간 관리업 무를 자치구로 위임하여 효율적으로 관리하고 어린이 실외활동을 늘리고 장려하기 위한 기반 환경을 마련 할 필요가 있다. 보육교사 및 자치구 환경보건담당 등 어린이 및 청소년 시설관계자를 대상으로 환경보건교 육을 실시하여 어린이 활동공간의 환경안전 관리 능 력을 키우고, 어린이 활동공간 안전관리 및 생활 속 유해물질 예방 가이드북을 제작 보급하여 시민참여 방식으로 유해물질 노출을 관리할 필요가 있다.

‘학교 환경보건인증 및 체험 프로그램 운영'을 통 해 환아 및 가족을 대상으로 환경성질환(피부질환, 호흡기질환, 알레르기 질환)의 예방관리 체험 프로 그램을 실시하여 환아 스스로 자기 관리를 향상할 수 있도록 한다. 아토피 안심학교(초등학교와 어린 이집 대상 환경개선사업과 아토피 환아 대상 교육), 발암물질 안심학교 (학교시설 및 학용품 대상 유해 성 평가 실시와 교육)등 어린이 안심학교 인증 프로 그램을 운영하여 학교 환경을 자발적으로 개선할 수

http://www.kseh.org/
있도록 한다.

'어린이 환경보건전담부서 설치'를 통해 서울시 어 린이 환경보건개선을 위한 연구조사 및 정책 및 제 도 마련 등을 추진한다.

\section{2) 모두의 건강과 안전 강화}

전체 서울 시민의 환경건강을 지키기 위해 민감 계 층의 환경보건관리 강화, 사회경제적 취약계층의 환 경보건실태 파악과 개선, 시민과 함께 하는 환경보건 사업, 교육 및 정보 제공 등의 과제를 선정하였다. ‘ 민감 계층의 환경보건관리 강화'를 통해 어린이 활동 공간 내 관리기준이 없는 유해화학물질의 관리 근거 를 마련하고, 유해물질 노출 저감을 위해 시민들이 스스로 유해물질에 대해 인지하고 노출을 최소화할 수 있도록 시민참여형 어린이 민감 유해물질 저감방 안을 마련(친환경 내장재 및 제품정보, 유해인자 독 성 및 안심정보 제공, 자발적 함유식품 표시제도 도 입)하며, 노령인구의 건강수명을 $10 \%$ 연장시키는 $+10 \%$ 프로그램(기존 보건사업과 연계한 환경유해인 자 노출실태 조사 및 저감 계획 운영)을 운영한다.

‘사회경제적 취약계층의 환경보건실태 파악'을 통 해 사회경제적 취약계층의 환경건강을 위한 서울시 전략을 수립(노출 실태 파악, 중장기 계획 수립, 협

J Environ Health Sci 2014; 40(5): 425-434 
의기구 구성)하고, 지역아동센터를 통한 취약계층 어 린이 보호 방안(유해요인 노출 실태 조사 및 환경개 선사업)을 마련한다.

'시민과 함께하는 환경보건사업'을 통해 환경보건 시민모니터링단을 구성하여 지역사회 환경보건문제 를 상시적으로 모니터링 할 수 있도록 하고, 발암물 질 없는 서울 만들기 캠페인을 통해 생활 환경에서 환경성질환을 유발하는 요인에 대해 시민인식을 제 고한다. '교육 및 정보 제공'을 통해 생활 속 화학물 질 유해성과 노출 저감을 위한 교육영상물 제작, 보 급하고 아토피 교육센터 교육을 기능을 확대하고 생 애 주기별 환경보건 정보를 제공한다.

3) 발암물질 및 환경호르몬 물질 등 생활 속 유해 물질 저감

발암물질 및 환경호르몬 물질 등 생활 속 유해물 질 노출을 최소화 하기 위해 유해물질 노출 관리, 유해물질 함유 제품 사용 관리, 생활환경 중 물리적 유해요인(소음, 생활 및 의료 방사선, 전자파) 관리, 실내공기질 개선 등 4 가지 과제를 선정하였다.

‘유해물질 노출 관리'를 위해 우선관리 대상 유해 물질을 선정하고 이 물질들에 대한 체계적 노출 관 리 정책을 마련한다. 디젤 연소 분진과 초미세입자 관리 대책을 마련하고, 인공향 성분 노출조사 및 불 필요한 남용을 억제하기 위한 근거를 마련한다, 서 울시내 소규모 사업장의 유해물질 사용 실태를 조사 하고 유해물질 배출을 관리한다.

‘유해물질 함유 제품 사용관리'를 통해 안전제품 권고기준을 제정하고 관련 정보를 구축한다. 또한 생 활용품 속 유해물질 저감을 위한 생산유통 관계자 협약 체결, 안전한 제품 구매를 돕는 시민녹색구매 가이드 북 제작 보급, 유해물질 저감형 방역사업 개 발 등이 포함된다.

'생활환경내 물리적 유해요인 관리'는 소음과 방사 선 등 물리적 요인에 대한 관리대책을 포함한다. 도 로교통, 항공, 생활 환경 및 주거지에서 발생하는 소 음을 저감하고 관리 대책을 마련한다. 자연환경과 생 활 환경 및 의료기기에서 발생하는 방사선의 노출에 대한 위해성에 대해 정보를 제공하고 노출 방지 대 책을 마련한다. 일상생활에서 노출 가능한 전자파와 관련된 건강영향 정보를 제공하고 노출 저감 방안을 제시한다. '실내공기질 개선'을 위해 실내공기질 관
리대상 시설의 관리제도 상의 제한점을 보완하고 관 리효율성을 높이기 위한 통합 관리 체계를 구축한다. 또한 수용체 중심 실내환경 관리요인 통합지표(유해 인자, 쾌적인자 포함)를 개발하고 이에 근거하여 실 내환경을 통합적으로 관리한다. 사회경제적 취약계 층의 거주공간의 실내공기질 조사와 주거환경 개선 을 지원한다.

\section{4) 환경보건기반강화}

환경보건 기반 강화를 위해 제도 기반 구축, 전문 대응 능력 구축, 조사연구 기반 구축, 환경성 유해 물질 감시 및 연구기능 강화, 지역사회 환경보건 역 량 강화를 추진한다. ‘환경보건제도 기반구축'을 위 해 환경보건조례를 제정하여 서울시 환경보건정책 제도기반을 마련하고 서울시 환경보건종합계획을 수 립하고 환경보건정책 및 사업관리를 위한 환경보건 위원회를 구성한다. '환경보건 전문대응능력 구축'을 위해 기후변화로 인한 건강영향 대책을 전담하는 부 서를 설치한다. 시민들에게 생활속 유해화학물질 정 보를 제공할 수 있는 환경보건 종합정보센터를 설립 하고 운영한다.

‘환경보건 조사연구 기반 구축’을 위해 서울시 환 경보건기초조사를 실시하고 서울시 구 단위를 포함 한 환경보건지표를 개발한다. 서울시 정책 및 사업 수립시 건강영향을 우선적으로 고려하여 정책을 추 진할 수 있도록 건강영향평가제도를 도입한다.

‘환경성유해물질 감시 및 연구기능 강화'는 지역사 회참여연구(Community-Based Participatory Research, $\mathrm{CBPR}$ ) 기능을 강화하고 환경보건센터를 유치하여 서울시민의 환경성질환을 연구, 관리한다. '지역사회 환경건강 능력 강화'는 자치구 보건소의 환경보건사 업역량을 강화하여 지역사회기반의 환경보건서비스 를 제공하도록 한다. 또한 지역사회 환경보건전문가 육성 프로그램을 개발하고 지역사회 보건의료전문가 (산부인과, 소아과 의사 등)를 활용한 환경보건교육 을 실시한다.

\section{IV. 고 찰}

서울시는 지속적이고 체계적인 환경보건정책 수행 을 위해 환경보건 전문가, 시민사회단체, 관련 공무 원이 참여하고 시민의견 반영을 위한 설문조사 등을 
통해 서울시 환경보건정책 로드맵(2013-2017)을 수 립하였다. 서울시의 환경보건정책 비전은 "건강한 환 경, 안심 서울"이며 이는 모든 서울 시민이 환경유 해인자로부터 안전한 사회를 지향함을 의미한다.

서울시의 환경보건정책은 국가 환경보건종합계획1) 을 반영하는 것이다. 지방정부의 환경보건 계획(Local Environmental Health Action Plan, LEHAP)을 통해 국가단위 환경보건계획(National Environmental Health Action Plan, NEHAP)을 확산하고 지역사회 참여를 이끌어 내는 효과를 도모할 수 있다. ${ }^{14)}$ 서울시 환경 보건정책보다 앞서 추진된 지방정부 환경보건계획은 충청남도 환경보건종합계획(2012-2016년) $)^{15)}$ 과 경기 도의 아토피 없는 경기도 종합계획(2011년) $)^{16)}$ 이 있 으나 정책 분야와 정책 포괄성에 차이가 있다.

서울시 환경보건정책은 환경보건법에 제시된 환경 보건종합계획 수립의 원칙인 수용체에 기반 ${ }^{17)}$ 하여 특히 어린이, 노인, 사회경제적 취약 계층 등 환경 보건 분야 민감 취약계층을 우선 고려하여 정책을 수립하였다. 어린이는 생물학적으로 성인에 비해 유 해물질 노출에 더 취약할 수 있으며(높은 흡수율과 대사율, 취약한 배설능력, 어린이 행동 습관, 불완전 한 면역체계, 긴 노출 시간 등 $)^{18)}$ 노인의 경우 유해 물질 노출에 대한 방어 기능이 감퇴되어 있어서 동 일한 수준의 유해물질 노출에도 더 심각한 생물학적 반응을 일으킬 수 있다. ${ }^{9)}$ 또한 사회경제적 취약계층 일반 집단에 비해 환경보건 위험 노출 빈도 또는 수 준이 높기 때문에 건강불평등을 해소하기 위한 중장 기적 계획이 필요하다. ${ }^{20)}$

서울시는 어린이 환경보건을 위해 어린이 활동공 간 관리 업무를 자치구로 이관하여 관리하고 기존에 운영하고 있는 학교 환경보건 인증 및 체험 프로그 램을 확장하여 추진할 예정이다. ${ }^{21)}$ 어린이 환경보건 전담 부서 설치는 미국의 환경보호청(EPA)산하 어린 이 전담 어린이 환경보건 사무국(Office of Children's Health Protection:OCEP)과 같이 어린이 건강에 대 한 연구 및 예방을 위한 정책 개발 사업을 추진하 기 위한 것으로 장기적 목표를 가지고 추진되어야 할 부분이다.

모두의 건강과 안전 강화를 위한 정책 과제는 어 린이, 노인, 사회경제적 취약계층의 환경보건 노출 실태를 파악, 개선하고 시민들이 환경보건 개선사업 에 모니터링과, 교육 등을 통해 참여할 수 있도록
하였다.

발암물질 및 환경호르몬 물질 등 생활 속 유해물 질 저감 정책 과제는 서울시에서 선정한 7대 발암 물질(디젤 배출 입자, 폼알데하이드, 석면, 라돈, 납, 벤젠, 다핵방향족 탄화수소)과 5대 환경호르몬(내분 비계교란물질)물질(과불화화합물, 트리클로산, 난연 제, 비스페놀A, 프탈레이트 $)^{23)}$ 등 생활속 유해 화학 물질 노출을 저감할 수 있는 제도를 마련하고 서울 시민이 스스로 노출을 저감 할 수 있도록 정보를 구 축하고 제공하는 것이다.

환경보건 기반 강화는, 환경보건제도 기반을 구축 하고 전문 인력을 구축하는 것을 과제로 하였다. 서 울시 환경보건조례 ${ }^{10)}$ 는 2013 년에 안이 제출되었으며 환경보건조례에는 환경보건 종합계획과 보건기초조 사, 환경보건지표 개발 등의 내용을 포함하고 있다. 또한 지역사회기반참여 연구(Community-Based Participatory Research, CBPR $)^{24)}$ 를 통해 지역사회 환경보건기반을 강화하고자 하였다.

서울시 환경보건정책을 원활히 추진하기 위해서는 적절한 재원 배분이 필요하며 서울시 환경보건정책 담당부서와 관련 부서 및 중앙정부, 자치구와의 원 활한 협력 체계가 구축되어야 할 것이다. 또한 환경 보건계획을 지속적으로 점검, 평가, 보완할 수 있는 추진 기구가 마련되어야 할 것이다

\section{V. 결 론}

서울시는 지속적이고 체계적인 환경보건정책 추진 을 위해 “건강한 환경, 안심 서울"을 정책비전으로 정하고 서울시 환경보건정책 로드맵(2013-2017)을 수립하였다. 서울시 환경보건정책으로 (1) 유해물질 로부터 어린이 보호, (2) 서울시민 모두의 건강과 안 전강화, (3) 시민 건강을 위협하는 발암물질 및 환 경호르몬 없는 서울, (4) 환경보건정책 기반 구축 등 의 주요 분야가 선정되었다. 서울시 환경보건정책의 원활한 수행을 위해서는 재원확보가 필요하며, 중앙 정부, 관련 부서, 자치구와의 협력체계를 구축하고 지속적으로 정책을 추진해 나갈 기구 마련이 필요하다.

\section{References}

1. Ministry of Education, Ministry of Health \& Wel- 
fare, and Environment. Ministry of Environment. Master Plan for Environmental Health (2011-2020), Ministry of Education, Ministry of Health \& Welfare, and Environment. Ministry of Environment, Korea, 2011. Sejong: Ministry of Education, Ministry of Health \& Welfare, and Environment. Ministry of Environment Press; 2011.

2. Ministry of Government Legislation, Environmental Health Act. Available: http://www.law.go.kr/ LSW/lsInfoP.do?lsiSeq=150143\#0000 [accessed 11 August 2014].

3. The Seoul Institute, Seoul Metropolitan Overview. Available: http://www.si.re.kr/file/download/seol/maps/ Indicator_Seoul_2010-1.pdf [accessed 11 August 2014].

4. Seoul Development Institute, Characteristic of Urban Environment from the Perspective of Everyday Life Safety in Seoul, Seoul: Seoul Development Institute Press:2010, p.14-15.

5. Statistics Korea, Air Pollution Status. Available: http://www.index.go.kr/potal/govindic/userPageCh.do [accessed 11 August 2014]

6. Statistical Research Institute, Korean Social Trends 2013, Daejeon: Statistical Research Institute Press: 2013, p. 259-265.

7. Korea Meteorological Administration, Climate Change Report (Seoul), Seoul: Korea Meteorological Administration Press: 2011, p.99-112.

8. Korea Meteorological Administration, Prospect Report for Climate Change in Seoul, Incheon, Gyeonggi-do, Seoul: Korea Meteorological Administration Press: 2012, p.42-50.

9. Korea Institute for Health and Social Affairs (KIHASA), 4th Public Health Index Survey for Seoul citizen, Seoul: Korea Institute for Health and Social Affairs (KIHASA) Press: 2010, p.51-136.

10. Seoul Metropolitan Government, Seoul Environment Health Act, Available: http://opengov.seoul. go.kr/section/341510?fileIdx=2\#pdfview[accessed 11 August 2014].

11. Seoul Metropolitan Government, 2013 Atopy Free Seoul Plan, Available: http://opengov.seoul.go.kr/ section/345902?fileIdx=0\#pdfview [accessed 11 August 2014].

12. Seoul Metropolitan Government, Seoul Metropolitan Government's Environmental Health Policy Road Map, Seoul: Seoul Metropolitan Government Press: 2013, p.9-14.
13. Seoul Metropolitan Government, Seoul Metropolitan Government's Environmental Health Policy Road Map, Seoul: Seoul Metropolitan Government Press: 2013, p.85-86.

14. World Health Organization (WHO) Europe, Local Environmental Health Planning-Guidance for Local National Authorities, Europe: WHO Regional Publications. Press: 2002, p.23-80.

15. Chungnam Provincial Government, Comprehensive Plan for Environmental Health in Chungchengnamdo, Hongseong: Chungnam Provincial Government, Press:2012, p.7-45.

16. Gyeonggi Research Institute, Strategy to achieve Atopy Free Gyeonggi-do, Suwon: Gyeonggi Research Institute, Press: 2012, p.145-152.

17. Korea Ministry of Government Legislation, Environmental Health Act, Available: http://www.law. go.kr/\%EB\%B2\%95\%EB\%A0\%B9/\%ED\%99\%98\% ЕА $\%$ B2\%BD $\%$ EB\%B3\%B4\%EA\%B1\%B4\%EB\% B2\%95 [accessed 11 August 2014].

18. National Institute of Environmental Research, Scientific Opinions on Exposure Recommendation Level for Susceptible Population, Incheon: National Institute of Environmental Research, Press: 2011, p.1-3

19. Ministry of Environment, Evaluation of Health Effect by Environmental Exposure in Elderly Population, Incheon: Ministry of Environment, Press: 2008, p. $15-18$

20. WHO, Closing the Gap in a Generation, Geneva: WHO press, Press: 2008. p.1-40

21. Seoul Medical Center, Camp Program for Children and Parents, Seoul: Seoul Medical Center, Press: 2012, p.1-7

22. United States Environmental Protection Agency (US EPA), Protecting Children's Environmental Health, Available: http://www2.epa.gov/children [accessed 11 August 2014].

23. Seoul Metropolitan Government, Seoul Metropolitan Government's Environmental Health Policy Road Map, Seoul: Seoul Metropolitan Government Press: 2013, p.293-334.

24. Community-Campus Partnerships for Health, Promoting Healthy Public Policy through CommunityBased Participatory Research: Ten Case Studies, Available: https://depts.washington.edu/ccph/pdf_files/ CBPR_final.pdf [accessed 11 August 2014]. 